\title{
Effect of dairy farm and milk refrigeration on microbiological and microstructural characteristics of matured Serra da Estrela cheese
}

\author{
Freni K. Tavaria, Patrícia J.M. Reis, F. Xavier Malcata* \\ Escola Superior de Biotecnologia, Universidade Católica Portuguesa, Rua Dr. António Bernardino de Almeida, P-4200-072 Porto, Portugal
}

Keywords: Microorganisms; Dairy products; Ewes' milk; Scanning electron microscopy

\begin{abstract}
This work was aimed at enumerating the viable microorganisms in ripened Serra da Estrela cheeses, manufactured from both refrigerated and non-refrigerated milk, in various dairies located throughout the demarcated region. Scanning electron microscopy was used to analyze the microstructure, and thus aid in understanding possible differences in their microbiological profile. The cheeses were allowed to ripen under controlled conditions, and sampled at 60, 90,120,150 and $180 \mathrm{~d}$ following manufacture. Viable numbers of lactic acid bacteria, staphylococci, Enterobacteriaceae and yeasts were obtained following standard plate counting on a number of selective media. Lactococcus was the most abundant genus (above $10^{8} \mathrm{cfu} \mathrm{g}^{-1}$ of cheese) up to $120 \mathrm{~d}$ of ripening. No significant microstructural differences were observed in cheeses manufactured in different dairies over the ripening process. However, microstructural differences were apparent between cheeses manufactured with refrigerated versus non-refrigerated milk.
\end{abstract}

\section{Introduction}

Traditional products are often considered a nuclear part of the cultural heritage of a nation, and they frequently account for the difference between positive and negative net profits of farmers in less developed, rural areas. However, empirical manufacturing practices and poor sanitary conditions associated with such practices are incompatible with the tighter control enforced by Public Health Offices, a situation that will eventually hamper the global trade of such products. One such example is Serra da Estrela cheese, which originates in the central region of Portugal and bears the name of the highest mountains in that country. This cheese is manufactured from raw ewes' milk and curdled with an aqueous extract of the wild thistle Cynara cardunculus, without addition of any commercial starter culture. Its manufacture follows traditional protocols (Macedo, Malcata, \& Oliveira, 1993) and relies on the unique features of the milk imparted by the local feed,

\footnotetext{
${ }^{*}$ Corresponding author. Tel.: + 35122 5580004; fax: + 351225090351 .

E-mail address: fxmalcata@esb.ucp.pt (F.X. Malcata).
}

coupled with the proteolytic specificity of the plant rennet and the pattern of curd breaking by hand. The raw milk is heated to ca. $30^{\circ} \mathrm{C}$, before the coagulant is added $\left(0.25 \mathrm{~g} \mathrm{~L}^{-1}\right.$, which is equivalent to 492.6 rennet units (RU) $\mathrm{mL}^{-1}$; $1 \mathrm{RU}$ is the amount of enzyme needed to coagulate $10 \mathrm{~mL}$ of milk at $30^{\circ} \mathrm{C}$ in $100 \mathrm{~s}$ (FIL-IDFInternational Dairy Federation, 1992). The curd is finally allowed to set for $30-45 \mathrm{~min}$ (note that the plant coagulant used is ca. 60-fold weaker than commercial rennet). Since no starter culture is added, the native microflora plays an important role during cheese ripening. Cutting of the curd (which occurs at ca. $\mathrm{pH}$ 6.5) is performed manually by stirring with bare hands, or with the help of a knife. The curd obtained, which is quite irregular in shape and size, is then moulded and pressed (ca. $2.45 \times 10^{5} \mathrm{~N} \mathrm{~m}^{-2}$ ). Ripening takes place at $8{ }^{\circ} \mathrm{C}$ and $95 \%$ relative humidity (RH) for $21 \mathrm{~d}$, and $11{ }^{\circ} \mathrm{C}$ and $85 \% \mathrm{RH}$ thereafter. The cheese is typically sold after $60 \mathrm{~d}$ of ripening.

In attempts to overcome the aforementioned sanitary issues, several studies (Macedo, Costa, \& Oliveira, 1996; Macedo \& Malcata, 1997; Macedo et al., 1993; Sousa \& Malcata, 1996, 1997; Tavaria \& Malcata, 1998, 2000) have 
characterized the physico-chemical, microbiological and biochemical profiles of this cheese variety. However, evidence that relates evolution of the microbiological profile with physical features such as microstructure is still scarce.

Milk refrigeration has been tested in attempts to avoid microbial proliferation between the milking and cheesemaking steps. However, refrigeration raises concerns pertaining to growth and proliferation of psychrotrophic bacteria, which are known to produce very active (and thermostable) proteolytic and lipolytic enzymes. These enzymes catalyze reactions that increase the levels of free fatty acids causing potential off-flavours, and partial solubilization of $\beta$-caseins. This causes a decreased diameter and an increased hydration degree of casein micelles, both of which promote a greater stability. As a result, a less compact and more fragile final coagulum is attained (Manfredini \& Massari, 1989).

Chemical composition, rheological behaviour and sensory attributes in foods, including cheese, are closely related to their microstructure. Although light microscopy has for long been used in microstructure studies, because it is rapid, and enables viewing of such cheese components as protein, fat and bacteria following specific staining, it is nevertheless constrained by its very shallow depth of focus (Kaláb, 1993). This constraint results in a lack of detail in the case of larger particles (e.g. fat globules and bacteria), so poor resolution is the result. Scanning electron microscopy (SEM) is able to overcome such limitations, and is able to visualize three-dimensional details, which include the protein network and the microbial inventory in cheese.

In this study, classical microbiological data (reflecting microbiological activity) were correlated with SEM images in attempts to validate differences among cheeses manufactured in four dairies along the Appélation d'Origine Protegée (AOP) region of Serra da Estrela, as well as between cheeses manufactured in the same dairy farm from non-refrigerated and refrigerated milk.

\section{Materials and methods}

\section{Cheese manufacture and sampling}

Experimental cheeses were produced on the same day within the typical ewes' lactation period (January-May), according to the traditional protocol (Macedo et al., 1993), in four selected certified dairies located in the AOP region. Five batches of cheese were produced in each dairy farm, and three cheese replicates were picked up at random from each batch throughout ripening (at 60, 90, 120, 150 and $180 \mathrm{~d})$. This resulted in a total of 75 independent cheeses, with ca. $1 \mathrm{~kg}$ each (3 replicates $\times 5$ ripening times $\times 4$ dairies +15 cheeses from refrigerated milk). After sampling for microbiological analyses, cheeses were stored as $2 \mathrm{~cm}^{3}$ blocks in a formal saline solution $(10 \mathrm{~mL}$ of $40 \%(\mathrm{w} / \mathrm{v})$ formalin and $90 \mathrm{~mL}$ of $0.94 \%(\mathrm{w} / \mathrm{v})$ sodium chloride), for at least 1 month, as described by Dean, Berridge, and
Mabbitt (1959), until microstructural observations were carried out.

\section{Microbiological analyses}

Ten grams of cheese were mixed with $90 \mathrm{~mL}$ of sterile $2 \%$ (w/v) aqueous sodium citrate solution (Merck, Darmstadt, Germany) as extraction buffer, and homogenized in a Stomacher Lab-Blender 400 (Seward Medical, London, UK). One-mL samples were taken, decimally diluted in sterile $0.1 \%(\mathrm{w} / \mathrm{v})$ aqueous peptone (Sigma Chemical, St. Louis, MO, USA), and then plated in duplicate on several media as described by Tavaria and Malcata (1998).

\section{Microstructural analyses}

Cheese blocks $(1 \times 1 \times 2 \mathrm{~cm})$ from the outermost, middle and bulk parts of the cheese were taken from each sample, and immersed in formal saline solution. Samples of formalin-fixed cheese were fractured by hand and dehydrated in a graded series of ethanol (10-100\%), each for $10 \mathrm{~min}$. The dehydrated samples were mounted on SEM stubs with conductive cement, and placed in the holder of a JSM-5600LV SEM (JEOL, Tokyo, Japan), operated at an accelerating voltage of $20 \mathrm{kV}$. Scanning electron micrographs were obtained under several magnifications.

\section{Statistical analyses}

Analyses of variance (ANOVA) were conducted for the viable numbers of the various microbial groups; preliminary logarithmic transformation of the data was required, to guarantee that they were independent and normally distributed (as required for validity of this analysis). The first ANOVA was conducted to assess significance of the dairy farm, whereas a second ANOVA was aimed at assessing significance of milk refrigeration. Fisher's protected least significant difference tests were used to make pairwise comparisons. The procedures were performed using the Statistical Software package from StatSoft (2001).

\section{Results and discussion}

\section{Effect of dairy farm}

The average counts of viable lactobacilli, lactococci, leuconostoc, enterococci, yeasts, Enterobacteriaceae and staphylococci in the cheeses manufactured in the four independent dairies are plotted in Fig. 1.

The ANOVA results (Table 1) indicated that both the dairy farm and the ripening time are statistically significant factors $(p<0.05)$ in determining the viable numbers of bacteria, irrespective of the microbial group. Lactic acid bacteria (i.e. lactobacilli, lactococci, leuconostoc and enterococci) were quantitatively the dominant groups at all ripening times and for all dairies, with viable numbers 

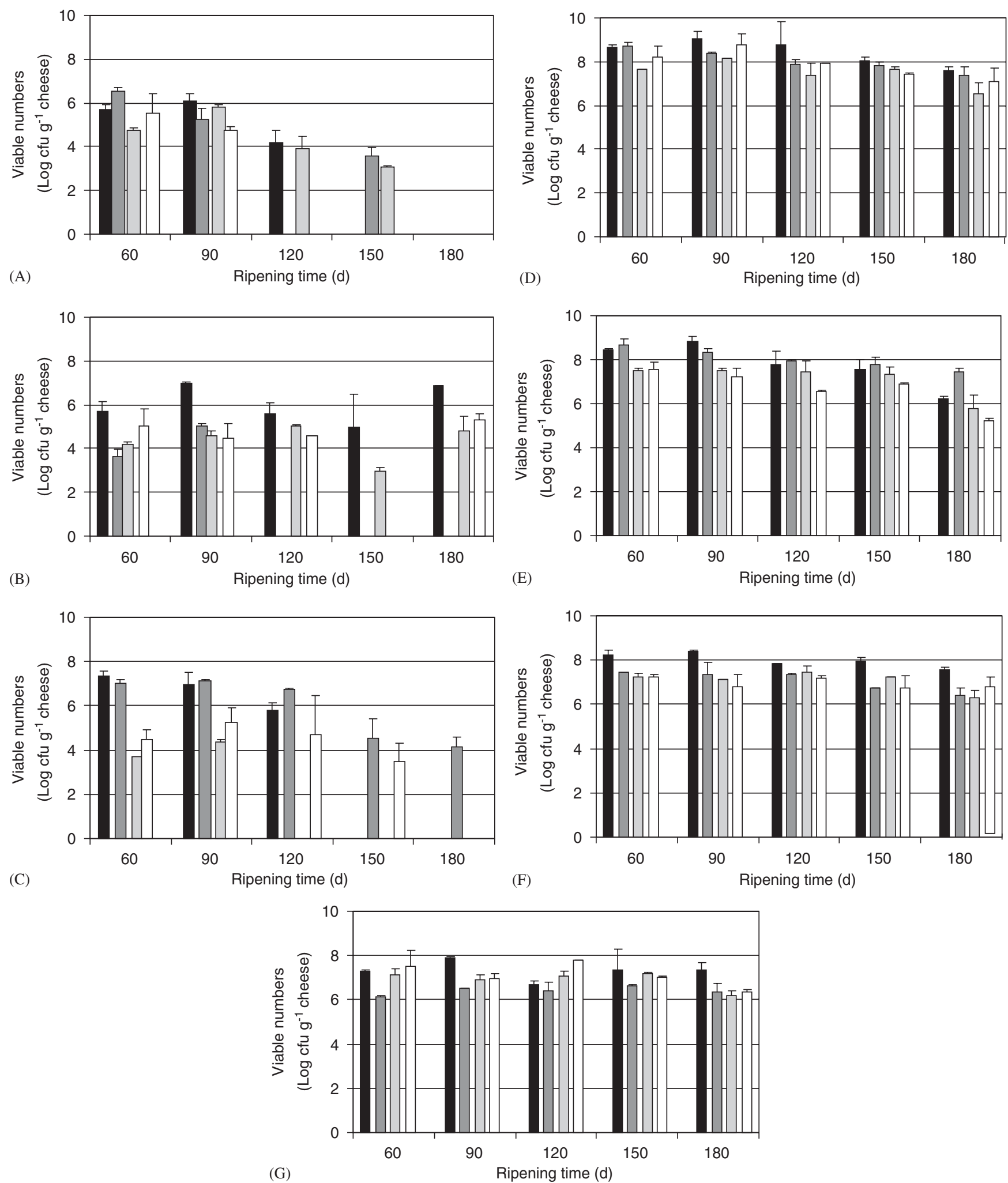

Fig. 1. Mean values, and corresponding standard deviations (error bars), of viable counts of Enterobacteriaceae (A), staphylococci (B), yeasts (C), lactococci (D), lactobacilli (E), leuconostoc (F) and enterococci $(\mathrm{G})$ in cheeses throughout ripening, from the four dairies: dairy A ( $\mathbf{\square})$, dairy B ( $\square$ ), dairy $\mathrm{C}(\square)$ and dairy $\mathrm{D}(\square)$.

ranging from $10^{7}$ to $10^{9} \mathrm{cfug}^{-1}$ of cheese and increasing with ripening time. These results are consistent with those reported for other artisanal cheeses produced in
Southern Europe from small ruminants' milk (Fernández-delPozo, Gaya, Medina, Rodríguez-Marín, \& Núñez, 1988; Fontecha et al., 1990; Tzanetakis, Litopoulou-Tzanetaki, 
Table 1

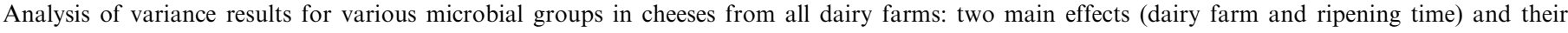
interactions

\begin{tabular}{|c|c|c|c|c|}
\hline Microbial group & $\begin{array}{l}\text { Effect of dairy } \\
\text { farm ( } p \text {-value) }\end{array}$ & $\begin{array}{l}\text { Effect of refrigeration } \\
(p \text {-value })\end{array}$ & $\begin{array}{l}\text { Effect of dairy farm } \times \text { ripening } \\
\text { time }(p \text {-value })\end{array}$ & $\begin{array}{l}\text { Effect of refrigeration } \times \text { ripening } \\
\text { time }(p \text {-value })\end{array}$ \\
\hline Enterobacteriaceae & 0.010 & 0.005 & 0.038 & 0.452 \\
\hline Staphylococcus & 0.000 & 0.710 & 0.001 & 0.175 \\
\hline Yeasts & 0.000 & 0.133 & 0.002 & 0.000 \\
\hline Lactobacillus & 0.000 & 0.004 & 0.039 & 0.000 \\
\hline Lactococcus & 0.004 & 0.410 & 0.919 & 0.590 \\
\hline Leuconostoc & 0.000 & 0.690 & 0.251 & 0.060 \\
\hline Enterococcus & 0.000 & 0.190 & 0.009 & 0.360 \\
\hline
\end{tabular}

\& Manolkidis, 1987). In La Serena cheese, manufactured from raw ewes' milk and coagulated with $C$. cardunculus (Medina, 1996), levels of viable microorganisms were similar to those reported in this study, whereas lactococci were reported to dominate during the first month of ripening in Manchego cheese and to be outnumbered thereafter by homofermentative lactobacilli. In ripened Fiore-Sardo cheese, an Italian variety also produced from raw sheep's milk without addition of starter, enterococci were reported to be the dominant microflora (Ledda, 1996).

Examples of scanning electron micrographs of cheeses manufactured from non-refrigerated milk, in two different dairies, are shown in Fig. 2. Small and large void spaces, which are scattered uniformly over the cheese matrix, can be observed, indicating the probable location of fat globules within the matrix. The average size of these globules range from 3 to $25 \mu \mathrm{m}$, in agreement with the report by Fontecha, Kaláb, Medina, Peláez, and Juárez (1996) for ewes' milk cheeses. Pérez-Munuera, Estévez, and Lluch (1999) reported that a similarly compact proteinaceous structure, in which the fat globules were uniformly distributed, is typical of enzymatic coagulation, and is often present in such ripened and pressed cheeses as Mahón and Manchego.

Such a microstructure is believed to impart a smooth, creamy texture to this cheese variety. Micrographs Fig. 2A and $\mathrm{B}$ show cheeses from the same dairy farm, whereas micrographs $2 \mathrm{C}$ and $\mathrm{D}$ show cheeses originated at a different dairy farm. Although substantial microstructural differences between these cheeses were expected (owing to the large variability of raw materials, coupled with such different manufacturing practices as cutting and pressing of curd), this was not observed. No apparent differences could be seen between Figs. 2A and C, probably due to the late time of ripening $(60 \mathrm{~d})$. In these two dairies, different patterns of coagulum cutting were used; in dairy farm A, the curd was cut manually via stirring with a knife, thus obtaining very irregular curd pieces; whereas in dairy farm $\mathrm{B}$, the curd was broken manually into very small pieces, before moulding. In the latter case, this should have resulted in a more compact matrix, as syneresis was more efficient due to the larger pores, which present lower resistance to the outflow of whey (Aichinger et al., 2003); however, this was not observed. Cutting procedures may influence microbial levels, because microorganisms tend to grow and develop as colonies along curd junctions (Parker, Gunning, Macedo, Malcata, \& Brocklehurst, 1998). Therefore, if the exposed surface area is increased by cutting finer curd pieces, potentially more microorganisms will grow on these fissures. A rise in numbers of lactic acid bacteria during the maturation process can be observed in Figs. 2E and $\mathrm{F}$. By $180 \mathrm{~d}$ (micrograph $2 \mathrm{~F}$ ), the numbers of cocci have increased significantly when compared to their counterparts by $60 \mathrm{~d}$ of maturation (micrograph $2 \mathrm{E}$ ).

\section{Effect of milk refrigeration}

The mean values (and corresponding standard deviations) of viable counts in cheeses manufactured with refrigerated and non-refrigerated milk in one of the dairies are shown in Fig. 3. The ANOVA results (Table 1) revealed that refrigeration produced significant differences in viable numbers $(p<0.05)$ only for Enterobacteriaceae (i.e. viable numbers were higher in cheeses produced from nonrefrigerated milk) and for lactobacilli (i.e. viable numbers were lower in cheeses obtained from non-refrigerated milk). Similarly to reports pertaining to other cheese varieties such as Manchego (Núñez \& Martinez-Moreno, 1976) and La Serena (Núñez, Medina, \& Gaya, 1989), the numbers of Enterobacteriaceae dropped to negligible levels by 120 and $150 \mathrm{~d}$ of ripening, respectively, in cheeses manufactured from refrigerated and non-refrigerated milk. This reinforces the view that refrigeration is effective in control of certain undesirable microorganisms, such as the enteric microflora. Conversely, milk refrigeration seems to favour yeast growth (Figs. 3C and 4C). Yeasts are believed to play important roles, such as utilization of lactic acid and increased rate of protein and triglyceride breakdown (Fernández-del-Pozo et al., 1988), which contribute to development of specific flavours (Dahl, Tavaria, \& Malcata, 2000).

Other microbial groups (mostly LAB) exhibited higher viable numbers in cheeses produced from non-refrigerated 

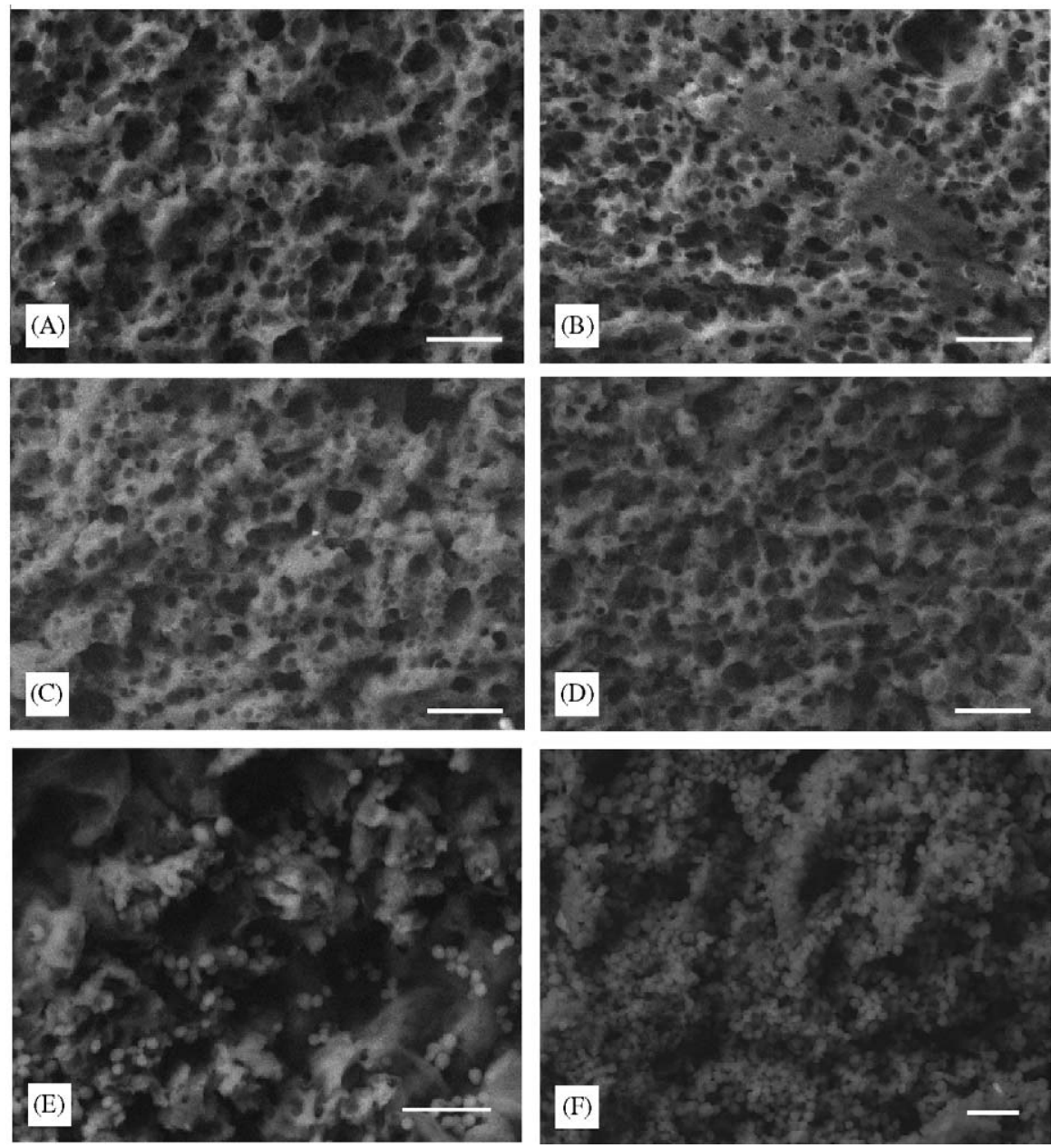

Fig. 2. Scanning electron micrographs showing microstructure in cheeses produced from non-refrigerated milk in two different dairies [A (A, B) and $\mathrm{B}(\mathrm{C}, \mathrm{D}, \mathrm{E}, \mathrm{F})]$ and ripened for $60 \mathrm{~d}(\mathrm{~A}, \mathrm{C})$ and $180 \mathrm{~d}(\mathrm{~B}, \mathrm{D})$ (scale bar $=20 \mu \mathrm{m})$, showing distribution of microorganisms in cheeses by $60 \mathrm{~d}(\mathrm{E}$; scalebar $=10 \mu \mathrm{m})$ and $180 \mathrm{~d}(\mathrm{~F} ;$ scale-bar $=20 \mu \mathrm{m})$.

milk up to $90 \mathrm{~d}$ of ripening. After this time, their numbers were higher in cheeses made from refrigerated milk. Micrographs of cheeses manufactured from refrigerated milk (Fig. 4) show that they have a coarser structure with larger spaces, thus reflecting a less compact coagulum, which prevails until the end of the ripening period. In samples of cheeses produced from refrigerated milk, larger voids of up to $200 \mu \mathrm{m}$ in diameter were observed (Figs. 4A and $\mathrm{B}$ ), and the resulting cheeses were creamier with a softer texture. Furthermore, the higher temperature of the non-refrigerated milk may induce faster acidification by the native bacteria, thus producing a coarser gel structure (which leads to a higher porosity) and favouring whey expulsion (Aichinger et al., 2003). Refrigeration, in turn, enhances microbial-mediated lipolytic activity, thus disrupting the fat globule network with a concomitant decrease in the number of these globules, as found by Juven, Gordin, Rosenthal, and Laufer (1981) and Núñez, Chavarri, and Núñez (1984). These trends can be observed in Figs. 4A and B. Refrigeration also affects the colloidal phase of the milk by partially solubilizing $\beta$-casein which tends to separate from the micelles, hence resulting in a less compact coagulum (Manfredini \& Massari, 1989). This effect is rather accentuated in the case of ewes' milk, owing to the higher $\beta$-casein percentage (ca. half of the total casein), when compared to cows' milk (only ca. one third), and due to the smaller size of ovine casein micelles.

Among the microorganisms detected, lactobacilli (Fig. 4C) and yeasts (Fig. 4D) were frequently found in our samples. Yeast cells are believed to prevail in the smear covering the outer surface of the cheese, as initially reported by Parker et al. (1998), where they play an active role despite their relatively low numbers. These findings are similar to the report of Pérez-Munuera et al. (1999) on non-cured, fresh cheeses (e.g. Herreño cheese).

The distribution of microorganisms within the cheese mass is well documented for cheeses such as Camembert (Kaláb, 1993), Gouda (Kaláb, 1977), St. Nectaire (Marcellino \& Benson, 1992), Cheddar (Brooker, 1979) and St. Paulin (Rousseau, 1988). Although the microbiological profile of Serra da Estrela cheese has been established, the species present as colonies within the microstructure cannot be elucidated before antibodies for each species are developed. In situ immunolabelling would then allow 

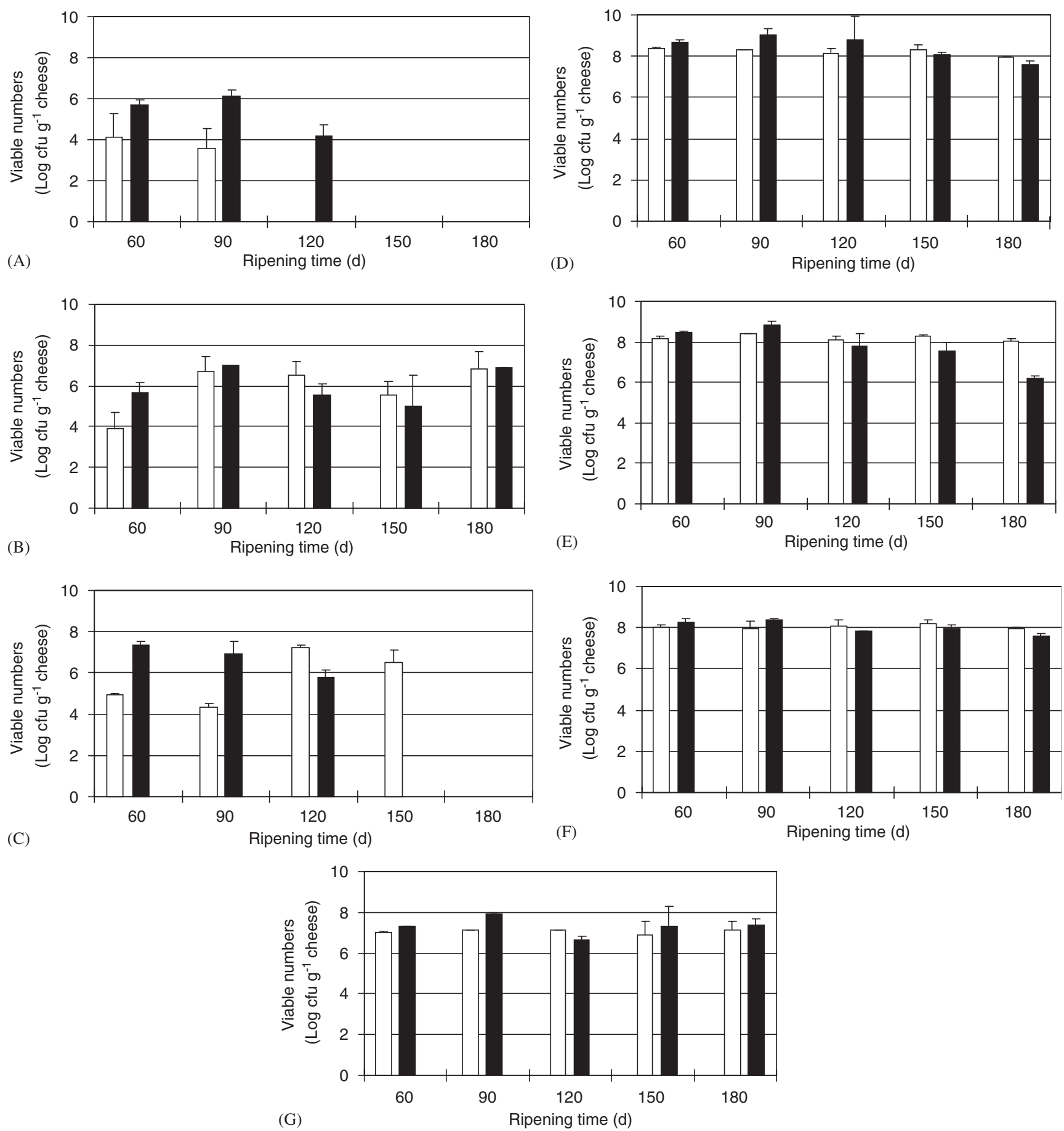

Fig. 3. Mean values (from a single dairy farm), and corresponding standard deviations even less, of viable counts of Enterobacteriaceae (A), staphylococci (B), yeasts (C), lactococci (D), lactobacilli (E), leuconostoc (F) and enterococci (G) in cheeses produced from non-refrigerated ( $\boldsymbol{\square})$ and refrigerated ( $\square$ ) milk.

bacterial species located as colonies throughout the cheese matrix to be properly identified.

\section{Conclusions}

The viable counts of microorganisms in Serra da Estrela cheese were greatly dependent on the farmhouse where manufacture took place. Lactic acid bacteria were quanti- tatively the dominant group, throughout ripening in all dairies, with numbers of viable cells ranging in $10^{7}-10^{9} \mathrm{cfu} \mathrm{g}^{-1}$ of cheese. Microstructural differences were not obvious in cheeses produced in different dairies, using distinct manufacturing practices. Milk refrigeration prior to cheese making appeared to control growth of Enterobacteriaceae, and to promote formation of a coarser protein matrix. Although the microstructural observations 

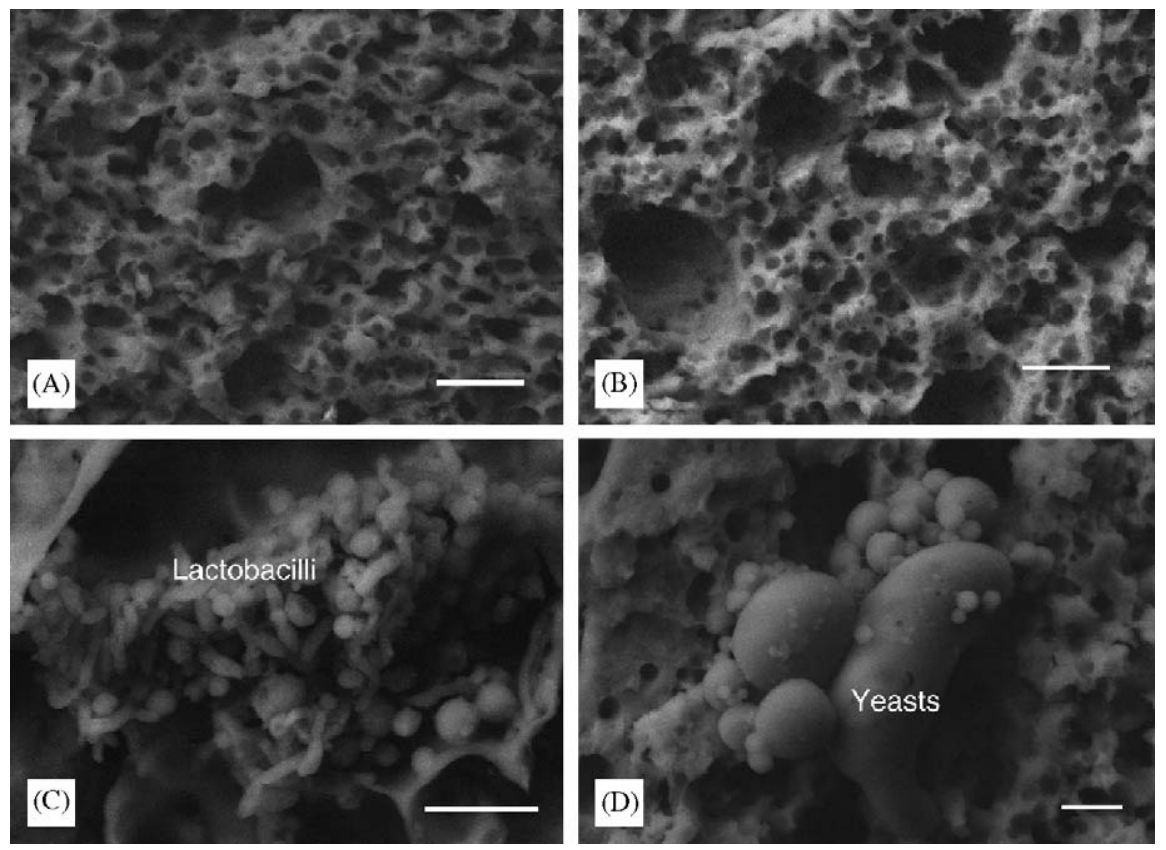

Fig. 4. Scanning electron micrographs showing microstructure in cheeses produced from refrigerated milk and ripened for $60 \mathrm{~d}$ (A) and $180 \mathrm{~d}$ (B) (scale bar $=20 \mu \mathrm{m})$, showing mixed colonies of bacilli and cocci $(\mathrm{C}$; scale bar $=10 \mu \mathrm{m})$ and colonies with yeasts $(\mathrm{D}$; scale bar $=20 \mu \mathrm{m})$.

did not permit detection of significant differences during ripening, differences were detected in cheeses manufactured from refrigerated milk. These cheeses had a looser matrix, where lactobacilli and yeasts predominated.

\section{Acknowledgements}

Financial support for authors Tavaria and Reis was provided by Ph.D. fellowships (BD/9572/96 and $\mathrm{BD} /$ 19752/99, respectively), issued by the Foundation for Science and Technology (FCT, Portugal), under the auspices of PRAXIS XXI program. Partial financial support for this research effort was obtained from project grant MICROCHEESE-Microstructure of Portuguese cheeses (POCTI/36197/BIO/2000), also by FCT.

\section{References}

Aichinger, P.-A., Michel, M., Servais, C., Dillman, M.-L., Rouvet, M., D'Amico, N., et al. (2003). Fermentation of a skim milk concentrate with Streptococcus thermophilus and chymosin: Structure, viscoelasticity and syneresis of gels. Colloids and Surfaces B, 31, 243-255.

Brooker, B. E. (1979). Milk and its products. In J. G. Vaughan (Ed.), Food microscopy (pp. 85-115). New York, NY, USA: Academic Press.

Dahl, S., Tavaria, F. K., \& Malcata, F. X. (2000). Flavour and microbiological relationships in Serra da Estrela cheese during ripening. International Dairy Journal, 10, 255-262.

Dean, M. R., Berridge, N. J., \& Mabbitt, L. A. (1959). Microscopical observations on Cheddar cheese and curd. Journal of Dairy Research, 26, 77-84

Fernández-del-Pozo, B., Gaya, P., Medina, M., Rodríguez-Marín, M. A., \& Núñez, M. (1988). Changes in the microflora of La Serena ewe's milk cheese during ripening. Journal of Dairy Research, 55, 449-455.
FIL-IDF Standard. (1992). Bovine rennets: Determination of total milkclotting activity. International Dairy Federation. Bulletin No. 157. Brussels, Belgium.

Fontecha, J., Kaláb, M., Medina, J., Peláez, C., \& Juárez, M. (1996). Effects of freezing and frozen storage on the microstructure and texture of ewe's milk cheese. Zeitschrift fur Lebensmittel-Untersuchung und-Forshung, 203, 245-251.

Fontecha, J., Peláez, C., Juárez, M., Requena, M. T., Gómez, C., \& Ramos, M. (1990). Biochemical and microbiological characteristics of artisanal hard goat's cheese. Journal of Dairy Science, 73, 1150-1157.

Juven, B. J., Gordin, S., Rosenthal, I., \& Laufer, A. (1981). Changes in refrigerated milk caused by Enterobacteriaceae. Journal of Dairy Science, 64, 1781-1784.

Kaláb, M. (1977). Milk gel structure. VI. Cheese texture and microstructure. Milchwissenschaft, 32, 449-458.

Kaláb, M. (1993). Practical aspects of electron microscopy in dairy research. Food Structure, 12, 95-114.

Ledda, A. (1996). Fiore-Sardo cheese. In T. M. Cogan, \& M. C. Rea (Eds.), Artisanal European cheeses-studies (pp. 35-37). Brussels, Belgium: European Commission (EUR 16788 EN).

Macedo, A. C., Costa, M. L., \& Oliveira, J. C. (1996). Changes in the microflora of Serra cheese: Evolution throughout ripening time, lactation period, and axial location. International Dairy Journal, 6, 79-94.

Macedo, A. C., \& Malcata, F. X. (1997). Secondary proteolysis in Serra cheese during ripening and throughout the cheese-making season. Zeitschrift fur Lebensmittel-Untersuchung und-Forshung, 204, 173-179.

Macedo, A. C., Malcata, F. X., \& Oliveira, J. C. (1993). The technology, chemistry, and microbiology of Serra cheese: A review. Journal of Dairy Science, 76, 1725-1739.

Manfredini, M., \& Massari, M. (1989). Small ruminant milk. Technological aspects: Storage and processing. Options Méditerranées, 6, 191-198.

Marcellino, N., \& Benson, D. (1992). Scanning electron and light microscopic study of microbial succession on Bethlehem St. Nectaire cheese. Applied and Environmental Microbiology, 58, 3448-3454. 
Medina, M. (1996). La Serena cheese. In T. M. Cogan, \& M. C. Rea (Eds.), Artisanal European cheeses-studies (pp. 17-21). Brussels, Belgium: European Commission (EUR 16788 EN).

Núñez, J. A., Chavarri, F. J., \& Núñez, M. (1984). Psychrotrophic bacterial flora of raw ewe's milk with particular reference to Gramnegative rods. Journal of Applied Bacteriology, 57, 23-29.

Núñez, M., \& Martinez-Moreno, J. L. (1976). Flora microbiana del queso Manchego. I. Evolución de la flora microbiana de quesos Manchegos artesanales. Anales del Instituto Nacional de Investigaciones Agrarias, 4, $11-31$.

Núñez, M., Medina, M., \& Gaya, P. (1989). Ewe's milk cheese: Technology, microbiology and chemistry. Journal of Dairy Research, 56, 303-321.

Parker, M. L., Gunning, P. A., Macedo, A. C., Malcata, F. X., \& Brocklehurst, T. F. (1998). The microstructure and distribution of micro-organisms within mature Serra cheese. Journal of Applied Microbiology, 84, 523-530.

Pérez-Munuera, I., Estévez, M., \& Lluch, M. A. (1999). Nota. Estudio de algunos quesos típicos españoles por microscopía electrónica de barrido. Principales modificaciones microestructurales causadas por la congelación. Food Science and Technology International, 5, 515-521.
Rousseau, M. (1988). Changes in the microstructure of Saint Paulin cheese during manufacture studied by scanning electron microscopy. Food Microstructure, 7, 105-113.

Sousa, M. J., \& Malcata, F. X. (1996). Comparison of plant and animal rennets in terms of microbiological, chemical and proteolysis characteristics of ovine cheese. Journal of Agricultural and Food Chemistry, 45, 74-81.

Sousa, M. J., \& Malcata, F. X. (1997). Comparative biochemical evolution during ripening of bovine, ovine and caprine milk cheeses manufactured with extracts of flowers of Cynara cardunculus. Zeitschrift fur Lebensmittel-Untersuchung und-Forshung, 205, 97-103.

StatSoft. (2001). Statistica for Windows, v. 6.0. Tulsa OK, USA: StatSoft. Tavaria, F. K., \& Malcata, F. X. (1998). Microbiological characterization of Serra da Estrela cheese throughout its Appélation d'Origine Protégée Region. Journal of Food Protection, 61, 601-607.

Tavaria, F. K., \& Malcata, F. X. (2000). On the microbiology of Serra da Estrela cheese: Geographical and chronological considerations. Food Microbiology, 17, 293-304.

Tzanetakis, N., Litopoulou-Tzanetaki, E., \& Manolkidis, K. (1987). Microbiology of Kopanisti, a traditional Greek cheese. Food Microbiology, 4, 251-256. 